地質学雑誌 第 112 巻 第 4 号 243-256 ページ, 2006 年 4 月

Jour. Geol. Soc. Japan, Vol. 112, No. 4, p. 243-256, April 2006

\title{
北海道穂別地域に分布するセノマニアンーチューロニアン階の浮遊性有孔虫層 序
}

Planktonic foraminiferal biostratigraphy of the Cenomanian-Turonian sequence in the Hobetsu area, Hokkaido, Japan

\section{山本真也* 長谷川卓*}

\section{Shinya Yamamoto* and \\ Takashi Hasegawa*}

2005 年 3 月 28 日受付.

2006 年 2 月 17 日受理.

* 金沢大学大学院自然科学研究科

Graduate school of Natural Science and Technology, Kanazawa University, Kakuma, Kanazawa, 920-1192, Japan

Corresponding author; S. Yamamoto, shinya@earth.s.kanazawa-u.ac.jp
Abstract

Continuous occurrence of international planktonic foraminiferal index species was recognized in the Middle to Upper Turonian successions in the Hobetsu area, Hokkaido, Japan. It enables us to assume the stratigraphic position of the upper limit of the Helvetoglobotruncana helvetica Zone, an important planktonic foraminiferal zonal boundary. Helvetoglobotruncana praehelvetica, Marginotruncana pseudolinneiana, and Praeglobotruncana gibba, which are also internationally recognizable species, occur associated with Helvetoglobotruncana helvetica. This association indicates that stratigraphic top of the Kajiyanosawa route should be assigned to close to the top of the total range of Helvetoglobotruncana helvetica. Correlation of the carbon isotope fluctuation through the Kajiyanosawa route with that of well-studied sections supports our chronostratigraphic interpretation from planktonic foraminiferal biostratigraphy

Concurrence of genus Archaeoglobigerina with Helvetoglobotruncana helvetica in the Middle Turonian of this area demonstrates that the timing of the first appearance of Archaeoglobigerina is older than previous known.

Key words: planktonic foraminifera, Helvetoglobotruncana helvetica, biostratigraphy, carbon isotope, Cenomanian, Turonian, Cretaceous, Yezo Group, Hobetsu, Hokkaido
は じめに

白亜紀から始新世初頭にかけては, 地球が非常に温暖化し た時代であったと考えられており（例えば, Frakes，1999; Zachos et al., 2001)，現世に最も近い温暖期（warm mode; Frakes et al., 1992）であることから当時の古環境を復元し ようとする試みは様々な側面から行われてきた。 それらの研 究の基礎となる化石層序は模式地が存在するヨーロッパや北 米で確立されてきた. Hardenbol et al.（1998）は中生界の 大型化石層序及び微化石層序を総括し, 海水準変動曲線やス トロンチウム同位体比曲線との関係を示し, 各バイオイベン トに対応する放射年代の值まで示している。，一方，北海道に 分布する白亜系の蝦夷層群は, 堆積速度が速いので北西太平 洋域における古環境に関するデー夕を千年オーダーで解析し 得る可能性がある。ただし，それを活かすためには精度の高 い国際対比を行うことが大前提となる．蝦夷層群は微化石を 豊富に含み，アンモナイトやイノセラムスなどの大型化石も よく産出する海成層であり，Matsumoto $(1942,1943)$ 以来 これらを用いた層序学的研究は盛んに行われてきた (Takayanagi, 1960; Toshimitsu and Maiya, 1986; 松本ほか, 1991; 西田ほか, 1992; Hasegawa，1999 など). 利光ほか

(C)The Geological Society of Japan 2006
（1995）は，本邦上部白亜系における大型化石，微化石，古 地磁気の統合層序を提案した. この統合層序は亜階レベルで の国際対比を目指した試みであったが，産出の稀な種や地域 的に限定されている種が年代指標種に含まれているという点 では問題が残っている.

また，この十年間では炭素同位体比曲線という新たな対比 ツールが登場し, その国際対比への有用性の議論が高まって いる. Voigt (2000) は，ヨーロッパにおける CenomanianTuronian 階の炭酸塩炭素同位体比デー夕を総括し, 得られ た統合炭素同位体比曲線, 大型化石層序，放射年代值の詳細 な関係を示した. Wiese and Kaplan (2001) は，北ドイツ を中心とした地域の Middle/Upper Turonian 亜階境界付近 での詳細な炭素同位体の変動を明らかにした上で，それらの 対比から, 境界の指標種となり得るいくつかの大型化石の初 出現層準の差異について議論した。 これらのヨーロッパにお ける研究は, 詳細な炭素同位体比層序を明らかにすることで 従来の生層序では成し得なかつた高精度かつ正確な地域間の 対比が可能であることを示している．蝦夷層群における炭素 同位体比の研究は，陸上高等植物起源の有機炭素を用いて, Cenomanian/Turonian 階境界を含む大夕張地域と達布地域 で初めて報告された（Hasegawa and Saito, 1993)。その後 
の研究で Cenomanian 期から Maastrichtian 期までの後期 白亜紀全般にわたつて陸源有機炭素と, ヨーロッパで報告さ れている炭酸塩の炭素同位体の長期的変動パターンがよく一 致することが北海道やサハリンで示された，これは，両者の 炭素同位体比が大気・海洋系中の $\mathrm{CO}_{2}$ の炭素同位体比変動に よって支配されていたためであると考えられている (Hasegawa, 1997; Hasegawa et al., 2003). Cenomanian/Turonian 階境界では, 炭素同位体比が顕著な正のエク スカーションを示すので, この層準を化学的鍵層として用い, 高精度国際対比がなされている (Hasegawa and Hatsugai, 2000)。最近では, Middle Turonian 期以降でも化学的鍵層 となり得る炭素同位体比イベントが明らかになりつつある (Hasegawa, 2003b; 土屋ほか, 2003).これら 2 つの研究は, 大型化石に基づいて地域内・地域間対比を行っているが，大 型化石種（特にInoceramus hobetsensis）の産出期間が比 較的長いこと, 化石帯の指標種の産出頻度が低い層位範囲が あること，ヨーロッパとの共通種が稀にしか産しないことを 考えると, Wiese and Kaplan（2001）に示された規模の小 さい複数の同位体比イベントの内のどれか一つを蝦夷層群の Middle-Upper Turonian 亜階で見られるイベントに対応さ せるのには現時点では不十分である. 国際対比という観点で は，大型化石（アンモナイト, イノセラムスなどの二枚貝類） よりも連続的に年代指標種を産する微化石による詳細な生層 序を確立し，それを用いた年代補正を行つた上で化学的鍵層 となり得る炭素同位体比イベントを検証する必要がある.

大夕張地域では，本山ほか（1991），平野ほか（1981）や Hasegawa（1999）などによって Cenomanian 階から Upper Turonian 亜階にかけて生層序学的研究がなされたが, その 南方に位置する穂別地域では，この層位範囲にわたる系統的 な生層序の研究はなされてこなかつた. Cenomanian 階から Upper Turonian 亜階は大夕張から穂別に向かって一般に夕 一ビダイト砂岩の挟在が少なくなっていき，より沖合的な相 を示しており (本山ほか, 1991; 高橋ほか, 2002 など), 深い 水深に二ッチェを持つ示準種となる浮遊性有孔虫の産出する 可能性も高い.

これらの現状を踏まえて本研究では，同地域の浮遊性有孔 虫層序のうち年代示準種を用いて浮遊性有孔虫帯区分を試み た. 特に Middle-Upper Turonian 亜階で重要な年代面が確 認されたので報告する，そして，蝦夷層群における既報の浮 遊性有孔虫層序や共産する大型化石との対応関係を議論し, 生層序におけるいくつかの問題点を示す．また，予察的では あるが，同時に炭素同位体比も測定し，ヨーロッパにおける 炭素同位体比曲線と対比が可能かどうかも検討した.

\section{地 質 概 説}

穂別北部地域（Fig. 1）に分布する白亜系は，高橋・和田 （1985）により中部蝦夷層群主部層と最上部層（佐久層）, 上部蝦夷層群及び函淵層群と区分された．その後，中・上部 蝦夷層群については松本らが大型化石による検討を報告し (松本ほか, 1989), 高橋ほか (2002) で稲里層, ヌタポマナ 个層，長和層が定義されている，本研究における層序区分は

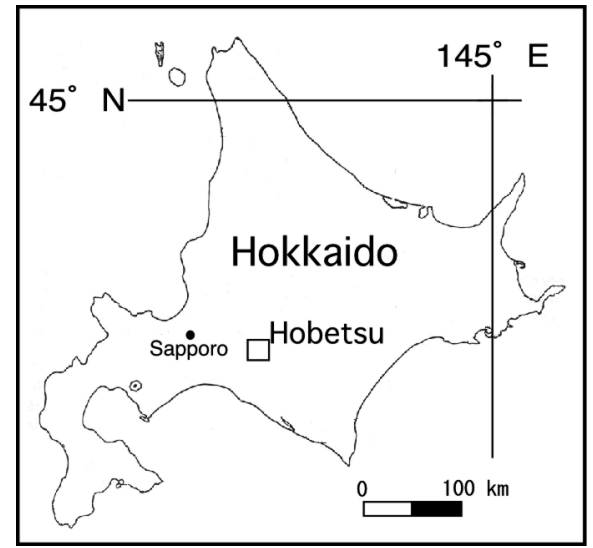

Fig. 1. Index map showing location of the Hobetsu area.

基本的に高橋ほか (2002) に従う. しかし, 彼らがヌタポマ ナイ層に用いた「下部層」・「主部層」は地層命名規約にの つとつた正式な部層の定義ではないので, 本研究ではヌタポ マナイ層「下部」・主部」と表記する. 本山ほか（1991）は 穂別地域に隣接の大夕張地域において，それまでの中・上部 蝦夷層群（Matsumoto, 1942, 1943）の岩相は一連整合であ ることから, 両層群を一括して蝦夷層群と呼んだ，穂別地域 でも同様の理由から一括名称としての「蝦夷層群」を用い る.

本研究では, 野外調査に基づいて地質構造が明瞭で連続的 な露出を持つ穂別ダムの南に位置する枝沢（以下, 穂別ダム 南の沢と記述）ルートと鍛冶屋の沢ルートの 2 つを選択し た. 穂別ダム南の沢 (Fig. 2c) に分布する稲里層は, NW$\mathrm{SE}$ の走向を持ち, 北東に $54 \sim 80^{\circ}$ で傾斜している. 岩相 は, 青灰色の塊状泥岩で, 稀に数 $\mathrm{mm}$ の凝灰岩薄層が挟在 する. 一方, 鍛冶屋の沢ルート（Fig. 2b）に連続して露出 するヌタポマナイ層は, $\mathrm{NW}-\mathrm{SE}$ の走向を持ち, 北東にお よそ $40^{\circ}$ で傾斜している. ヌタポマナイ層は高橋ほか (2002) によって「主部」と「下部」に分けられており，「下部」は 帯緑色砂岩と凝灰質シル卜岩の互層からなっている. 高橋ほ か（2002）では記載されていないが，「下部」の最上部には 細粒から中粒の層厚約 $40 \mathrm{~m}$ の帯緑色砂岩が挟在し, 登川峠 付近の尾根を形成している. また, 「主部」は葉理の発達し た砂質シルト岩が卓越し, 数 $\mathrm{mm}$ の白色粘土化した凝灰岩 薄層が頻繁に挟在する. 一部は凝灰質シルト岩に漸移するが, 上部に向かい細粒化する傾向がある. 鍛冶屋の沢ルートでは, 地層は概して東に傾斜する同斜構造で分布するが，「主部」 の下部には小褶曲による繰り返しが確認された（Fig. 2d）. また, 前述の繰り返しより下位では地層と地表面がほぼ同じ 傾きであるために，同一層準が連続して分布している， ヌ夕 ポマナイ層「下部」に尾根があり, 露出が不良のため連続セ クションにおける試料採取はできなかったが，又タポマナイ 層「下部」を追跡し，2 つのルートにおける層序の上下関係 を明らかにした. ヌタポマナイ層「下部」の分布は地形的に も明瞭に現れており, 少なくとも穂別ダム西岸まで南に連続 していることを確認している. 


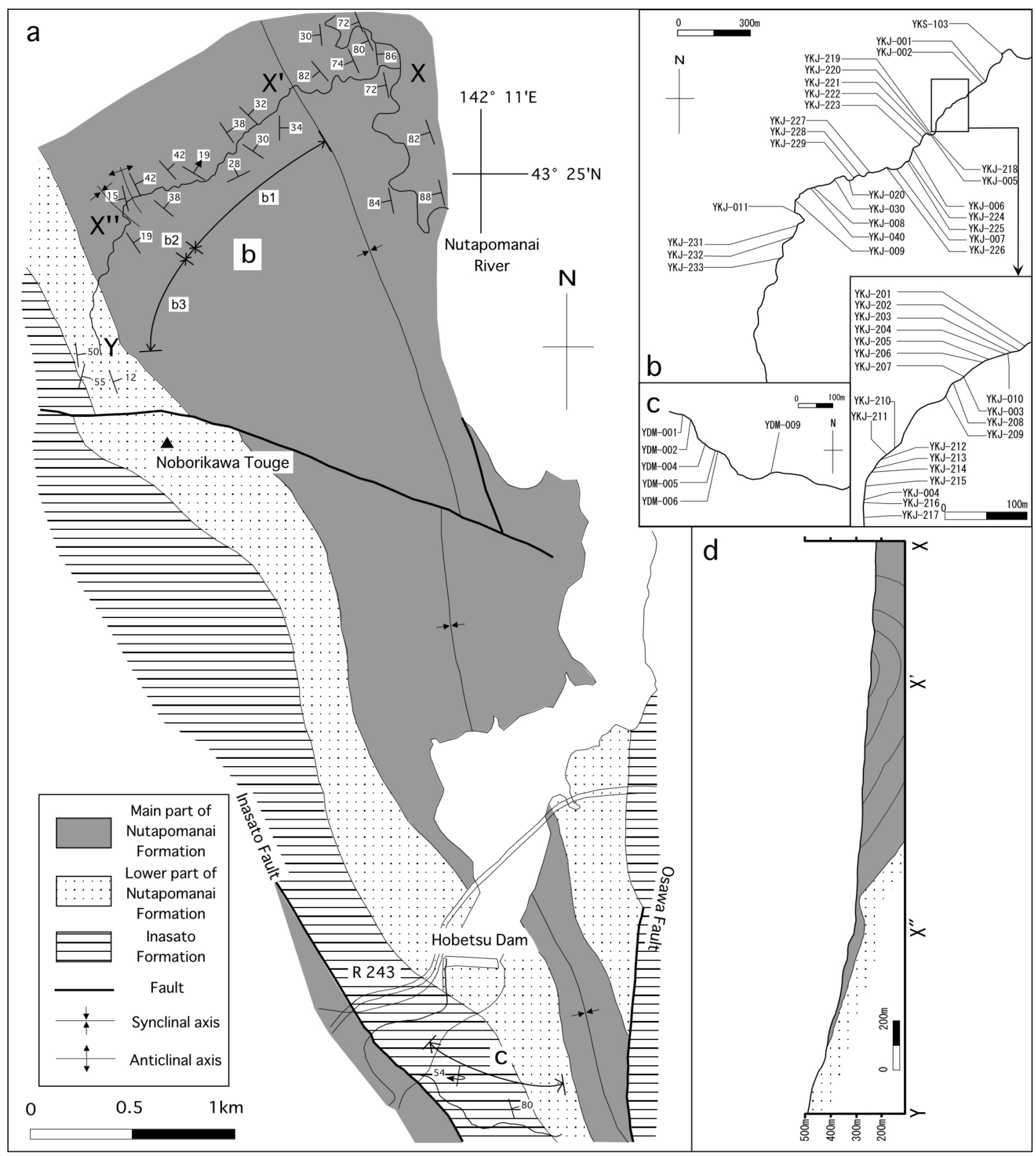

Fig. 2. Map (a) showing locality of selected two routes studied (b and c). Distribution of lithostratigraphic units are modified after Takahashi et al. (2002) with our original data. b, c: Maps showing sampling localities in the Hobetsu area; b: the Kajiyanosawa route, c: the route of a tributary of the Hobetsu River located south of the Hobetsu dam site. d: Geologic cross section along the Kajiyanosawa (b).

\section{試料 · 手法}

\section{1. 大型化石}

大型化石サンプルは鍛冶屋の沢から採取した. ノジュール および母岩から直接得たイノセラムスについて，層位分布図 に示した（Fig. 3).

\section{2. 浮遊性有孔虫処理用試料}

浮遊性有孔虫分析用の試料は，鍛冶屋の沢及び穂別ダム南 の沢から採取した (Fig. 2a). 試料間の平均的な層序学的間 隔は $20 \sim 50 \mathrm{~m}$ である. 又タポマナイ層「主部」の上部で は特に細粒な岩相であり, 浮遊性有孔虫が良好に保存されて いることが予想されたため，該当区間では $2 \sim 10 \mathrm{~m}$ 間隔で 


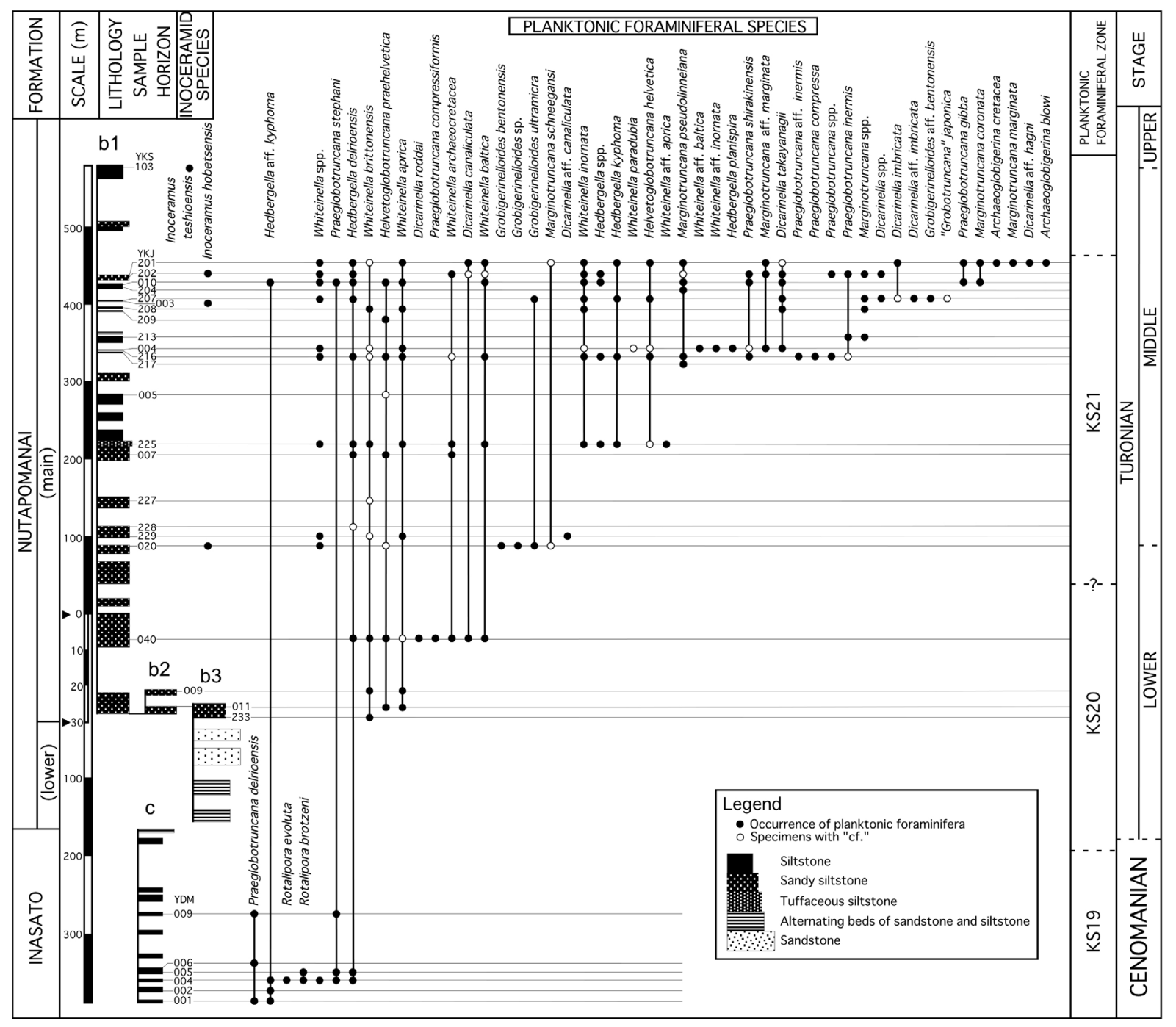

Fig. 3. Stratigraphic distribution of inoceramid species (left hand) and planktonic foraminiferal species (right hand) along two studied routes in the Hobetsu area. Designations at the top of each column (b1, b2, etc) correspond to those of the routes indicated in Fig. 2. Note that the scale is changed between the solid triangles.

試料を採取した. 各々の試料につき乾燥重量で約 $240 \mathrm{~g}$ を直

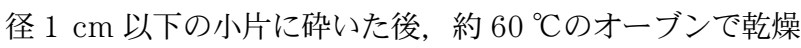
させ，硫酸ナトリウムーナフサ法（米谷・井上, 1973）を用 いて処理し，200メッシュの篩で水洗し乾燥させた．残渣の うち 80 メッシュより大きい個体について実体顕微鏡を用い て全ての浮遊性有孔虫を拾い出した.

\section{3. 炭素同位体比分析用試料}

炭素同位体比分析用の試料は，鍛冶屋の沢から採取した泥 岩で浮遊性有孔虫処理に用いたものと同一試料である.

試料はマイクログラインダーを用いて粉末化し， $5 \mathrm{~N}$ の塩 酸に 24 時間浸し，炭酸塩を除去した。 その後，遠心分離機 を用いて酸の除去を行った. 乾燥試料は, 錫カップに約 8 mg 秤量し, NBS19 を用いてキャリブレーションされている 米国インディアナ大学地質科学教室生物地球化学研究室設置 の Costech 社製 TC/EA 元素分析装置直結の連続フロー型質 量分析装置 ThermoFinnigan 社製 Delta Plus XP にて分析
した.このとき, 有機物含有量（TOC）についても同時に 分析值が得られた. 分析值は以下の式で PDB 標準試料に対 する $\delta^{13} \mathrm{C}$ 值として示した.

$$
\delta^{13} \mathrm{C}=\left\{\left({ }^{13} \mathrm{C} /{ }^{2} \mathrm{C}\right)_{\text {sample }} /\left({ }^{13} \mathrm{C} /{ }^{12} \mathrm{C}\right)_{\text {standard }}-1\right\} \times 1000
$$

測定された同位体比は, 同位体比が既知である研究室内標 準試料（アセトアニリド）を 16 試料に 1 回の割合で分析し 補正を行つた. 標準試料の分析精度 $(2 \sigma)$ は $0.03 \%$ 以下で あった. 試料分析は 2 回行い, その再現性は分析精度内に収 まっていた. 2 回測定の平均值をもって議論に用いるデー夕 とした.

採取した泥岩試料の中で任意に選択した 12 試料は, Bustin et al. (1983) の標準処理手順に従い, 破砕した泥岩 をペレット化し研磨した後, MPV-2 顕微鏡下で白色光およ び蛍光を用いて有機物組成を確認した. 


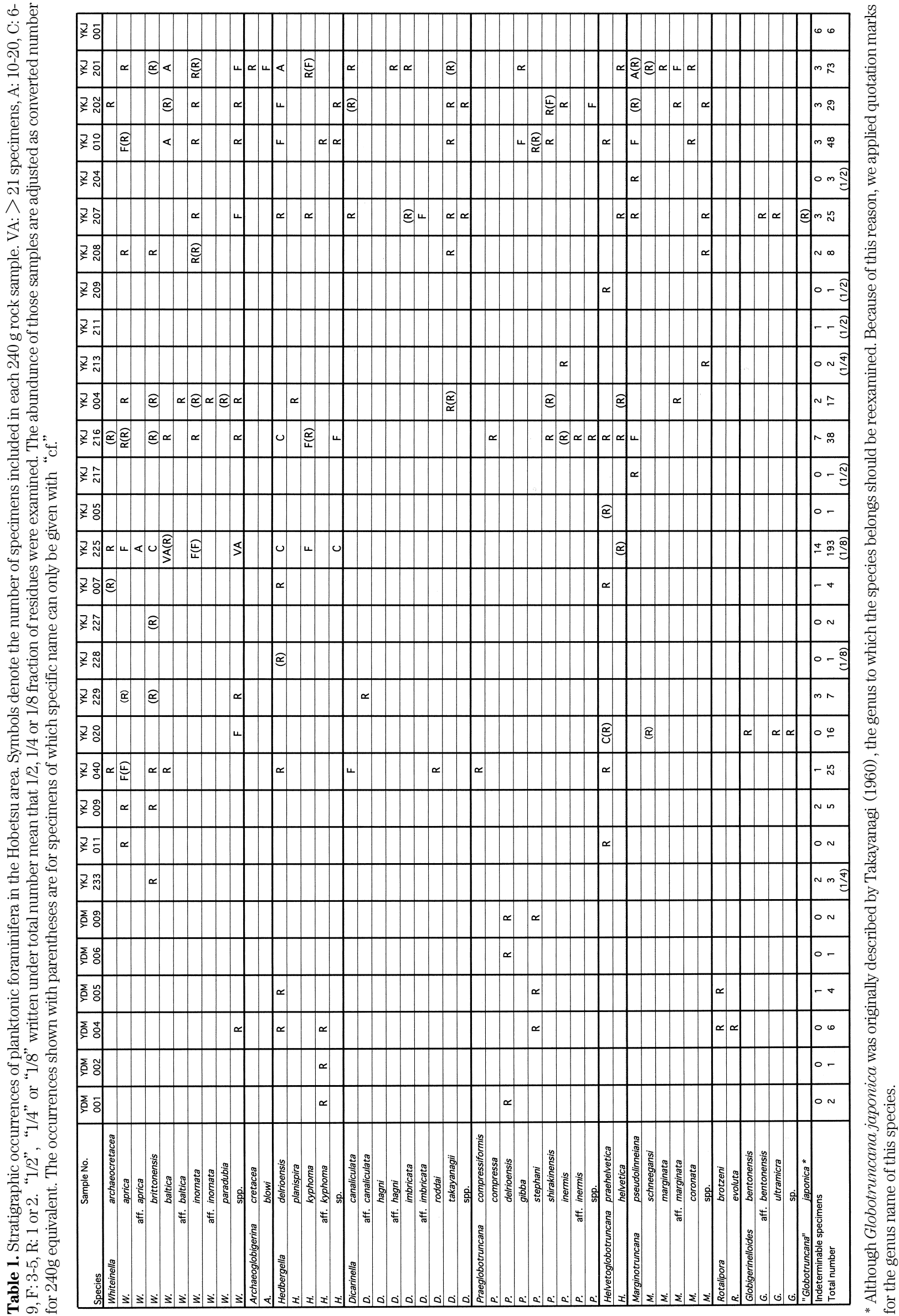




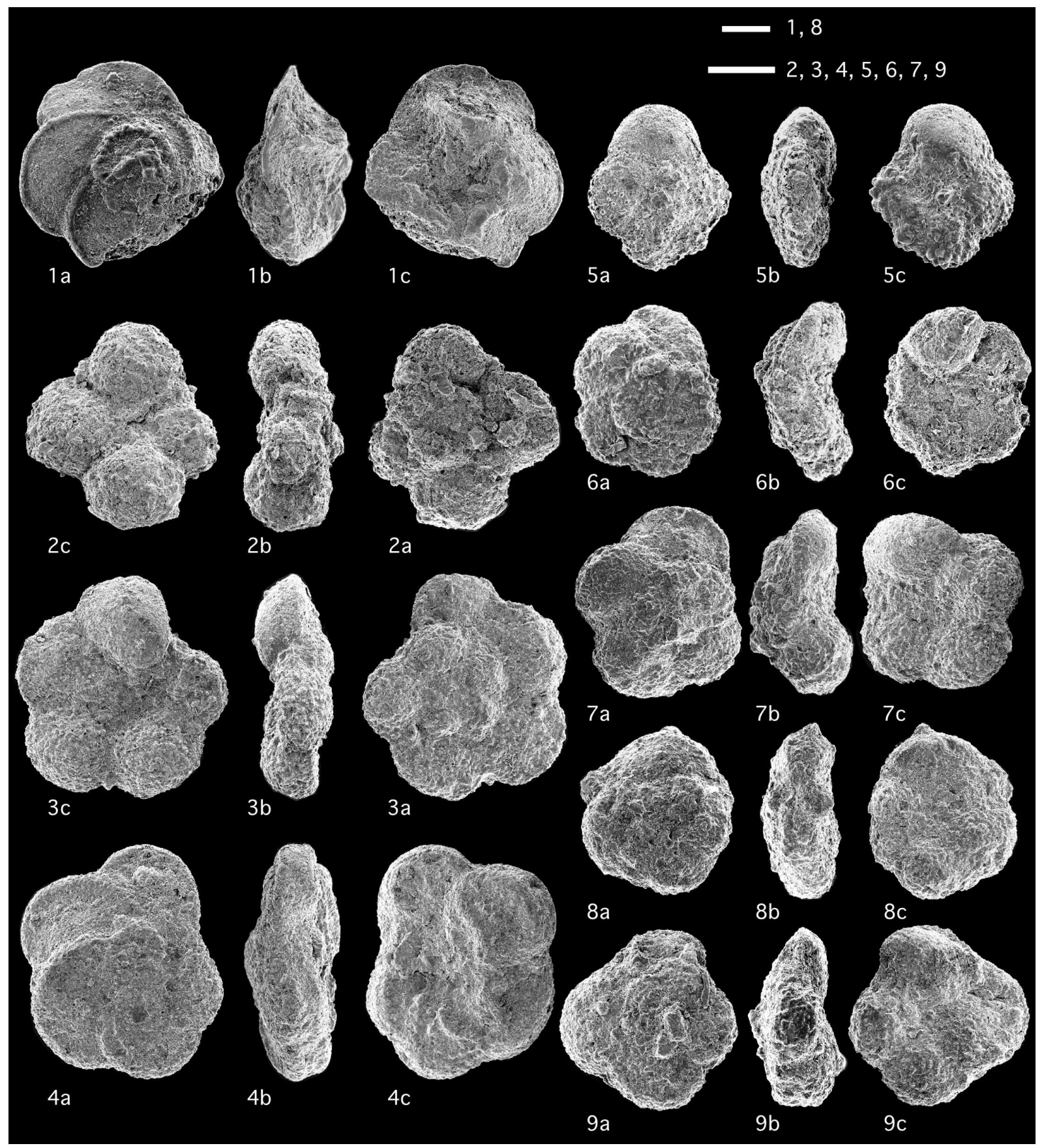

Fig. 4. Stratigraphically important planktonic foraminiferal species. All specimens are deposited in the Department of Earth Sciences, Faculty of Science, Kanazawa University. a: spiral view, b: lateral view, c: umbilical view. (1) Rotalipora brozteni (Sigal), sample loc. no. YDM-005. (2) Helvetoglobotruncana praehelvetica (Trujillo), sample loc. no. YKJ-007. (3) Helvetoglobotruncana helvetica Bolli, sample loc. no. YKJ201. (4) Marginotruncana pseudolinneiana Pessagno, sample loc. no. YKJ-010. (5) Praeglobotruncana delrioensis (Plummer), sample loc. no. YDM-001. (6) Dicarinella roddai (Marianos and Zingula), sample loc. no. YKJ-040. (7) Praeglobotruncana gibba Klaus, sample loc. no. YKJ-201. (8) Archaeoglobigerina cretacea (d’ Orbigny), sample loc. no. YKJ-201. (9) Archaeoglobigerina blowi Pessagno, sample loc. no. YKJ-201. Scale bars $=100 \mu \mathrm{m}$.

結果

\section{1. 大型化石}

ヌタポマナイ層「主部」の中部から上部（YKJ-003, 020, 202; Fig. 3) にわたり Inoceramus hobetsensis Nagao and Matsumoto（亜種は区別していない; 以下 s.l.と表記）の産出
が確認された. Inoceramus teshioensis Nagao and Matsumoto の産出がヌタポマナイ層「主部」の上部（YKS-103; Fig. 3) で確認された

\section{2. 浮遊性有孔虫}

穂別ダム南の沢及び鍛冶屋の沢において 60 試料を検討し， そのうち 30 試料から浮遊性有孔虫を抽出した（Table 1). 

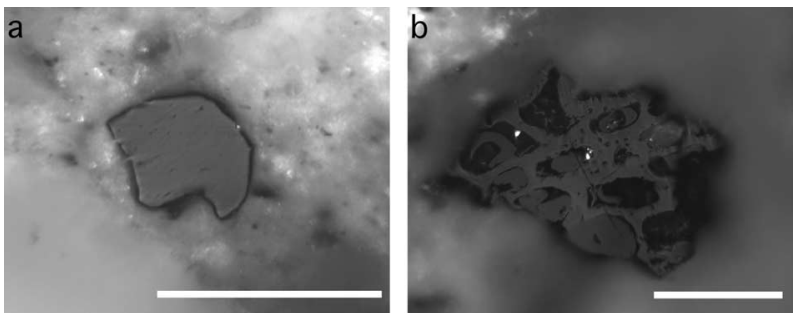

Fig. 5. Kerogen observed under microscope with reflected light. (a) Vitrinite from YKS-103. (b) Semifusinite from YKJ- 217. Note a well-preserved cell structure in semifusinite demonstrating its origin from cellular lignins of terrestrial vascular plant. Scale bars $=60$ $\mu \mathrm{m}$.

登川峠付近の林道に露出するヌタポマナイ層下部の泥岩を 除けば，浮遊性有孔虫はほぼ連続的に産出する (Fig. 3)。稲 里層では, 有孔虫の保存は良く殼表面の再結晶化がほとんど なく, キールや表面装飾がよく保存されている. しかし, 個 体数は少なく 5 〜 10 個体程度しか産せず, 同層上部では全 く産出しない. 一方, ヌタポマナイ層「主部」の下部の砂質 シルト岩の試料からの有孔虫の産出は稀であるが, 同層上部 のシルト岩の試料からは豊富に産出する. 保存は中程度で殼 表面が再結晶化しており, 臍部はほぼ埋まり, キール等も不 明瞭であることがある.このような個体については, 食紅に よる染色を施して鑑定を行つた. 層準によつては, 殼表面の 再結晶化がほとんどなく口孔を確認できる保存の良い個体も いくつか得られている（例えばYKJ-201）. 以下に世界の他 地域でも広く産する種（Caron, 1985 など）を中心に，下位 から上位に向かって浮遊性有孔虫の産出を報告する.

稲里層からは, Rotalipora brotzeni (Sigal) (Fig. 4-1), Praeglobotruncana delrioensis (Plummer) (Fig. 4-5), Rotalipora evoluta (Sigal) が特徵的に産出する. Hedbergella delrioensis (Carsey), Praeglobotruncana stephani (Gandolfi) とWhiteinella spp.が産出している が，それらは上位のヌタポマナイ層からも散在的に産出する.

ヌタポマナイ層「主部」の最下部付近（YKJ-009, 011, 233）ではWhiteinella属が優勢であり, Helvetoglobotruncana praehelvetica (Trujillo) (Fig. 4-2) を確 認した. その上位 (YKJ-040) ではそれらに加え, Dicarinella 属Dicarinella canaliculata (Reuss), Dicarinella roddai (Marianos and Zingula) (Fig. 4-6) の産出が認められ た. その約 $100 \mathrm{~m}$ 上位の YKJ-020 では, Marginotruncana cf. shneegansi (Sigal) の初産出が確認された. 更に 約 $130 \mathrm{~m}$ 上位のヌタポマナイ層「主部」の中部（YKJ-225） にはHelvetoglobotruncana helvetica Bolli (Fig. 4-3) の 初産出が認められる. H. helvetica はヌタポマナイ層「主 部」の上部からも連続的に産出する. YKJ-217 より上位のヌ タポマナイ層「主部」の上部では, 産出する種数及び個体数 が増加する傾向にある. YKJ-217 ではMarginotruncana pseudolinneiana Pessagno (Fig. 4-4), YKJ-010 では Praeglobotruncana gibba Klaus (Fig. 4-7), YKJ-201 で はArchaeoglobigerina blowi Pessagno（Fig. 4-9）と
Table 2. Carbon isotopic ratio and total organic carbon content (TOC) along the Kajiyanosawa route. Samples with asterisk on the head were performed in a petrographic study to certify predominant terrestrial origin of organic matter.

\begin{tabular}{ccc}
\hline Sample & $\begin{array}{c}{ }^{13} C_{\text {org }} \text { vs. PDB } \\
(\%)\end{array}$ & $\begin{array}{c}\text { TOC } \\
(\%)\end{array}$ \\
\hline *YKS103 & -24.91 & 0.70 \\
YKJ001 & -24.52 & 0.58 \\
YKJ002 & -24.75 & 0.53 \\
*YKJ201 & -24.51 & 0.55 \\
YKJ202 & -24.51 & 0.58 \\
YKJ203 & -24.61 & 0.71 \\
YKJ010 & -24.34 & 0.42 \\
YKJ204 & -24.73 & 0.72 \\
YKJ205 & -24.56 & 0.72 \\
YKJ206 & -24.37 & 0.56 \\
*YKJ207 & -24.67 & 0.62 \\
YKJ003 & -24.79 & 0.67 \\
YKJ208 & -24.51 & 0.70 \\
*YKJ209 & -24.58 & 0.61 \\
YKJ210 & -24.51 & 0.59 \\
YKJ211 & -24.56 & 0.65 \\
YKJ212 & -24.40 & 0.63 \\
*YKJ213 & -24.28 & 0.73 \\
YKJ214 & -24.83 & 0.71 \\
YKJ215 & -24.39 & 0.62 \\
YKJ004 & -24.71 & 0.55 \\
YKJ216 & -24.74 & 0.40 \\
*YKJ217 & -24.43 & 0.65 \\
YKJ218 & -24.48 & 0.67 \\
*YKJ219 & -24.08 & 0.23 \\
YKJ005 & -24.76 & 0.54 \\
YKJ220 & -24.76 & 0.60 \\
*YKJ221 & -24.94 & 0.64 \\
YKJ222 & -24.72 & 0.59 \\
YKJ223 & -24.37 & 0.47 \\
YKJ006 & -24.53 & 0.56 \\
*YKJ224 & -24.18 & 0.40 \\
YKJ225 & -24.44 & 0.34 \\
YKJ007 & -24.78 & 0.52 \\
YKJ226 & -24.54 & 0.45 \\
YKJ227 & -24.72 & 0.44 \\
*YKJ228 & -24.02 & 0.96 \\
YKJ229 & -24.56 & 0.75 \\
YKJ020 & -24.49 & 0.63 \\
YKJ030 & -24.51 & 0.62 \\
YKJ008 & -24.02 & 0.49 \\
YKJ040 & -24.12 & 0.46 \\
YKJ009 & -24.24 & 0.55 \\
YKJ011 & -24.00 & 0.38 \\
*YKJ231 & -23.77 & 0.66 \\
YKJ232 & -24.09 & 0.20 \\
*YKJ233 & -23.79 & 0.48 \\
\hline & & \\
\hline & &
\end{tabular}

Archaeoglobigerina cretacea (d’ Orbigny) (Fig. 4-8) の初産出がそれぞれ認められ，YKJ-010ではHelvetoglobotruncana praehelvetica の終産出が確認された. 鍛冶屋の沢ルートの最上部では Dicarinella 属とMarginotruncana属も主要な構成要素となり, 特に $M$. pseudolinneiana が特徵的に多産する.

\section{3. 有機物組成}

鍛冶屋の沢セクションの 12 試料について有機物組成を確 認するためにケロジェン観察を白色光及び蛍光下の光学顕微 鏡で行った. これらの試料におけるケロジェンは, ほとんど 


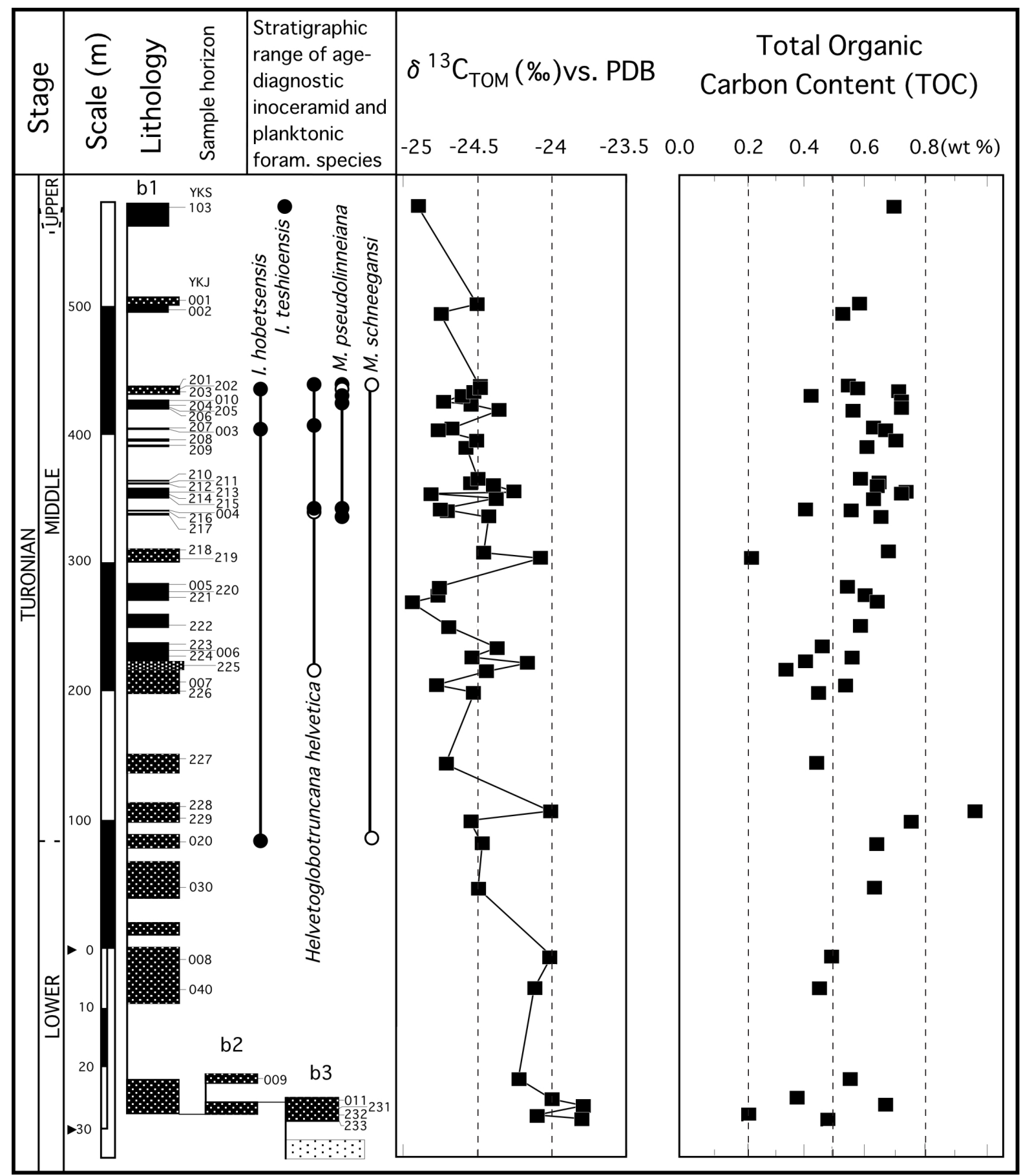

Fig. 6. Stratigraphic fluctuations of $\delta{ }^{13} \mathrm{C}$ of terrestrial organic matter and total organic carbon content (TOC) along the Kajiyanosawa route. Stage boundaries for the Hobetsu area are based on biostratigraphy discussed in this study. See Fig. 3 for legend.

が陸源高等植物の木質部リグニンに由来すると考えられるビ トリナイト，イナーチナイト（セミフジニット及びフジニッ ト）によって占められていた（Figs. 5a,b)，蛍光を発するア モルファナイトやアルジナイトは確認することができず，陸 源高等植物以外の起源をもつ有機物は $1 \%$ 以下で，ほとんど 観察することができなかつた.

\section{4. 有機炭素同位体比}

穂別地域鍛冶屋の沢ルートの有機物炭素同位体比と全有機
炭素量の值を Table 2 に，それらの層序学的な変動を Fig. 6 に示した．鍛冶屋の沢ルートの炭素同位体比は上位に向か いー $23.7 \%$ から $-24.9 \%$ へと減少する傾向を示し, 本ルー トの中位にあたる YKJ-221 で最小值をとる. 以後, 便宜上 この層準を境として，下半部と上半部に区分する. 下半部は YKJ-233 のー23.7 \% から YKJ-221 の-24.9 \%に至る $0.8 \%$ の負へのシフトによって特徵づけられる. 一方, YKJ-221の 直上で YKJ-219にかけて約 $0.9 \%$ の正へのシフトが見られ 
るが, 本ルートにおける上半部では約－ $24.6 \%$ 付近を中心に $0.5 \%$ 程度の変動を繰り返し, 最上部の YKS-103 でわずかに 負 $(-24.9 \%$ ） ヘシフトする. 有機炭素含有量（TOC）の 值は $0.2 \sim 1.0 \%$ の範囲にあり, 特記すべき変動は示さなか った (Fig. 6).

\section{考察}

\section{1. 浮遊性有孔虫による年代論}

白亜紀の浮遊性有孔虫層序については, Caron (1985) が 総括している. Sliter（1989）は太平洋域で石灰岩に含まれ る浮遊性有孔虫を薄片鑑定し, それらのデータを総括してい る.これらの中には白亜紀の浮遊性有孔虫の各種の生存期間 が示されており，熱帯・亜熱帯地域の種を用い, Hauterivian 階から Maastrichtian 階をそれぞれ 28 および 31 の浮遊 性有孔虫帯に区分している（Caron, 1985; Sliter, 1989)。ま た初めに述べたように，ヨーロッパ堆積盆における Hardenbol et al.（1998）の国際年代層序総括では Berriasian 階か ら Maastrichtian 階の 31 の浮遊性有孔虫帯を採用し, 各帯 を特徵付けるバイオイベントに対応する放射年代を示してい る. 大夕張地域では既に Cenomanian 階から Turonian 階に かけて浮遊性有孔虫帯の認定がなされている（Hasegawa, 1997，1999）が，本研究地域でも年代の示準種となる熱帯・ 亜熱帯種が連続的に産出していることから, 浮遊性有孔虫帯 の認定が可能である．当報告ではS Sliter（1989）の帯区分に 基づいてその年代論を展開する. Hardenbol et al. (1998) の上部白亜系の浮遊性有孔虫帯は Sliter（1989）のものと対 応しており, Hardenbol et al. (1998) に示された各化石帯 の放射年代值を Sliter（1989）の帯区分に対して適用するこ とができる.

（1）KS19 帯＼cjkstart稲里層から産出するPraeglobotruncana delrioensis とRotalipora brotzeni は共に Cenomanian 階を特徵づける種である. Sliter（1989）によると， P. delrioensis は KS15 帯中部から KS19a 帯まで, R. brotzeni は KS17 帯から KS19a 帯上部まで生存する. したがって, 稲里層は $R$. brotzeni の示す年代から Cenomanian 階 （KS19b，20 帯に相当する上部を除く）に対比されると考え られる. また同時に，1 層準（YDM-004; Fig. 3) のみながら R. brotzeni と Whiteinella spp.が共産している. Sliter (1989) では, Whiteinella baltica が KS19a 帯上部から, その他の Whiteinella 属の種は KS19b 帯から産出するとさ れている. 大夕張地域では, R. brotzeni と Whiteinella spp.の共存が KS19b 帯下部で報告されている（Hasegawa, 1999)。穂別ダム南の沢ルートの稲里層からは KS19 帯の指 標種である Rotalipora cushmani (Morrow) が全く産して いないことから化石帯を明確に認定することはできないが, 上述の状況から YDM-004 が KS19a と KS19b 境界付近に位 置していると考えるのが最も妥当であろう。したがって，同 層の浮遊性有孔虫を産する層位範囲は KS19 帯の MiddleUpper Cenomanian 亜階に相当する可能性が高い．

（2）KS20 帯 Caron (1985) やSliter（1989）によれば, この区間はWhiteinella 属を中心とする比較的低い多様度
によって特徵づけられ，大夕張地域でもこのことが確かめら れている (Hasegawa, 1995; 高嶋ほか, 1997). ヌタポマナ イ層「主部」の下部でも浮遊性有孔虫の産出は稀であり，そ の多様度も低い.しかし，この層準は岩相がやや粗いことか ら, 古水深が浅かった可能性があり, また保存不良により多 様度に偏りが生じたことも否定できない. したがって, 本研 究で見られる低い多様度は KS20 帯を推定する根拠にはなら ないと考えられる.しかし, Dicarinella roddai (Fig. 4-6) の産出によって年代層序範囲を Lower Turonian 亜階から MiddleTuronian 亜階下部と推定することができる（YKJ040; Fig. 3). D. roddai は元来, Lower Turonian 亜階を示 す種とされていた（Marianos and Zingula, 1966）が，大夕 張地域では, Uppermost Cenomanian 亜階から Middle Turonian 亜階下部までの産出が確認されており，特に $W$. archaeocretacea 帯前後で多産する（Hasegawa, 1999; 長 谷川, 2000). ヌタポマナイ層「主部」の下部から Rotalipo$r a$ 属の産出がないことも合わせて考察し, D. roddaiの産 出層準が Cenomanian 階ではなく, Lower Turonian 亜階か ら Middle Turonian 亜階下部にあたるものと考えられる.

（3）KS21 帯 穂別地域におけるHelvetoglobotruncana helveticaの初産出はヌタポマナイ層「主部」のYKJ-216 で 確認され，それ以上の数層準からも産出することから KS21 帯 (H. helveticaの全生存帯) を認定することが可能であ る. また, YKJ-225 でH. cf. helvetica が確認されることか ら，KS21 帯下限が YKJ-225 より下位にあることが示唆され る

一方, H. cf. helvetica の初産出層準の上位約 $100 \mathrm{~m}$ で, Marginotruncana pseudolinneiana の初産出が確認され た. M. pseudolinneiana は KS21 帯上部にその初産出基準 面（FAD）がある (Sliter, 1989). Nishi et al. (2003) で示 された蝦夷層群における浮遊性有孔虫種の生存範囲による と, M. pseudolinneiana は H. helvetica 帯の中部に初産 出するとされており本研究の結果と矛盾しない.

またPraeglobotruncana gibba の産出が KS21 帯の $M$ pseudolinneianaの産出する範囲で確認された. Hasegawa（1999）は穂別地域に隣接する大夕張地域で $P$. gibba の終産出を, H. helvetica の産出層準の上位約 $50 \mathrm{~m}$ から報告しているが, M. pseudolinneiana とP. gibbaの 共産関係は確認されていない. また Nishi et al. (2003) に よれば, 蝦夷層群における P. gibba の層序学的産出範囲の 上限は, H. helvetica の初産出よりも下位の KS20 帯にある (Fig. 7)。低緯度地域ではP. gibba が KS19 帯から KS21 帯 まで生存し, H. helvetica と同時消滅をする（最終出現面: LAD が同層準にある）とされており（Sliter, 1989), H. helvetica や M. pseudolinneiana と生存範囲が重なることに 矛盾はない (Fig. 7)。したがって, 本研究で初めて P. gibba の北西太平洋域における層序的産出範囲が低緯度地域とほぼ 一致し, KS21 帯上部に及ぶことが確かめられたことになる.

更に本研究では穂別地域で Helvetoglobotruncana praehelvetica の終産出が, 鍛冶屋の沢ルートにおける最上部の H. helvetica 産出層準（YKJ-201）のわずかに（約 $13 \mathrm{~m} ）$ 


\begin{tabular}{|c|c|c|c|c|c|c|}
\hline $\begin{array}{l}\text { D.: Dicarinella } \\
\text { M.: Marginotruncana } \\
\text { W.: Whiteinella }\end{array}$ & Caron (1985) & Sliter (1989) & & This study & Nishi et al. (2003) & \multirow[b]{2}{*}{ 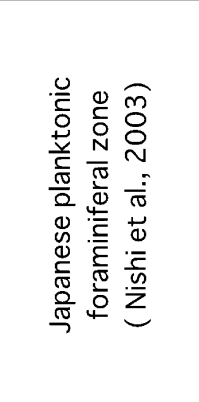 } \\
\hline $\begin{array}{l}\text { International } \\
\text { planktonic } \\
\text { foram. zone } \\
\text { (Caron, 1985; } \\
\text { Sliter, 1989) }\end{array}$ & 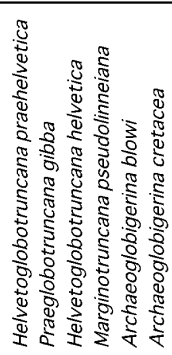 & 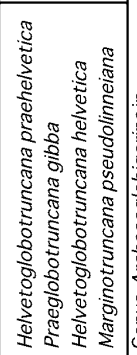 & 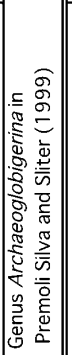 & 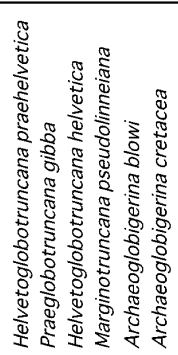 & 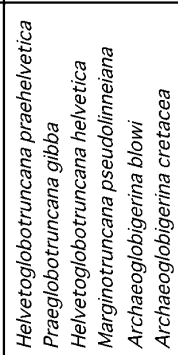 & \\
\hline $\begin{array}{l}\text { D. concavata } \\
\text { Zone (KS 23) }\end{array}$ & & & & & & $\begin{array}{c}M . \\
\text { sinuosa Zone }\end{array}$ \\
\hline 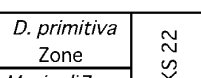 & & & & & & $\begin{array}{c}\text { M. } \\
\text { pseudolinneiana } \\
\text { Zone }\end{array}$ \\
\hline M. sigalizone & & & & & & \\
\hline $\begin{array}{l}\text { Helvetoglobotruncana } \\
\text { helvetica Zone } \\
\text { (KS 21) }\end{array}$ & & & & & & $\begin{array}{c}\text { Helvetoglobotruncana } \\
\text { helvetica Zone }\end{array}$ \\
\hline $\begin{array}{l}\text { W. archaeocretacea } \\
\text { Zone (KS 20) }\end{array}$ & & & & & & $\begin{array}{c}\text { W. archaeocretacea } \\
\text { Zone }\end{array}$ \\
\hline
\end{tabular}

Fig. 7. Stratigraphic distribution of planktonic foraminiferal species summarized by various authors discussed in this paper.
下位にあることを確認した. H. praehelvetica の LAD につ いて, Caron（1985）はH. helveticaの LADより下位に位 置すると考えたが, その後, Sliter（1989）は太平洋の試料 から H. helvetica の LAD よりもわずかに上位にその LAD を置いた（Fig. 7)。蝦夷層群においては, Nishi et al. (2003) がH. helvetica と H. praehelvetica の日本に於け る終産出は同層準だと考えた，上下関係に相違はあるものの， これら 2 種の LAD が互いに近傍にあるという点で上述 3 論 文の見解は一致している.

以上のように, 本研究において確認された H. praehelveticaの終産出, および $H$. helvetica, M. pseudolinneiana, P. gibba, H. praehelveticaの共産関係は, KS21 帯最上部の特徵である (Fig. 7)。すなわち, 本研究で はH. helvetica の終産出層準を確認できなかったが，その 直上に KS21/KS22 帯境界が存在することを強く示唆してい る.

ただし, Archaeoglobigerina 属の層位分布はこの解釈で は説明できない. H. helvetica とArchaeoglobigerina 属 の共産はこれまで他地域で報告されていない．膨大なデータ を網羅している Caron（1985）やPremoli Silva and Sliter （1999）でもこの属の FAD をH. helvetica の LAD の上位 に置いているが，その意義について，大型化石を含めて後に 考察する.

\section{2. 大型化石による年代論}

イノセラムス類はアンモナイト類に比べ豊富に産出するこ とから, 蝦夷層群分布域では野外調査において示準化石とし て容易に用いることができる，日本においては，共産するア ンモナイト類を用いて本邦のイノセラムス帯をヨーロッパの 年代層序区分と対比する試みがなされている（利光ほか, 1995). Inoceramus hobetsensis（s. 1.）は日本において Middle Turonian 亜階の代表種とされているが, この種はヌ タポマナイ層「主部」の中部から上部にかけて散点的な産出 があり，その産出範囲をI. hobetsensis 帯であると認定し
た. また, Inoceramus teshioensis は Upper Turonian 亜 階の代表種で, ヌタポマナイ層「主部」の最上部 (I. hobetsensis（s. 1.）終産出層準の上位約 $140 \mathrm{~m}$ ）から産出すること から，鍛冶屋の沢ルートでは少なくとも Upper Turonian 亜 階に達していることを示している.

また， ヌタポマナイ層「下部」は，浮遊性有孔虫が産出せ ず，上下層との層序関係から KS 19 帯上部と KS20 帯の Upper Cenomanian 亜階から Lower Turonian 亜階である と推測される。松本ほか（1994）の検討では, Lower Turonian 亜階を示す Mytiloides subhercynicus (Seitz) や Fagesia sp.が得られており，この推定と調和的である.

\section{3. 炭素同位体比曲線亡生層序の統合亡国際対比}

本研究で炭素同位体比分析に用いた試料の有機物は, 陸上 高等植物の木質部リグニンに由来する有機物が大部分を占め る. セミフジニットに保存されている細胞構造は, その起源 が樹木に由来することを示している (Fig. 5b)，蛍光発色す る有機物がほとんど観察されなかったことは, 海洋起源有機 物の寄与がほとんどないことを示している. 陸源有機物が卓 越するという特徵は, 大夕張地域や古丹別地域の上部白亜系 からも報告されている (Hasegawa, 1997, 2001; Hasegawa and Hatsugai, 2000). また, 蝦夷層群中の陸源高等植物由 来の有機物は広域から由来し, 運搬過程で十分擋汼されてい ると考えられている．また，それらを全岩で測定する場合， 短期的（例えば, 季節変動や数年規模の異常気象現象など） な要因による植物生理学的な影響は平均化され，これによつ て長期的な炭素同位体比変動曲線のパターンが変わることは ないと考えられる（長谷川, 2003a)。これらのことから，本 研究で得られた有機物炭素同位体比の変動が有機物組成の変 化によって生じたものではなく, 大気海洋系の $\mathrm{CO}_{2}$ の炭素同 位体比変動を反映しており, 大夕張地域やサハリン南部ナイ バ地域の有機炭素同位体比曲線及びヨーロッパの炭酸塩炭素 同位体比曲線と対比が可能であると解釈した.

鍛冶屋の沢ルートでは, 生層序学で重要な示準面がいくつ 


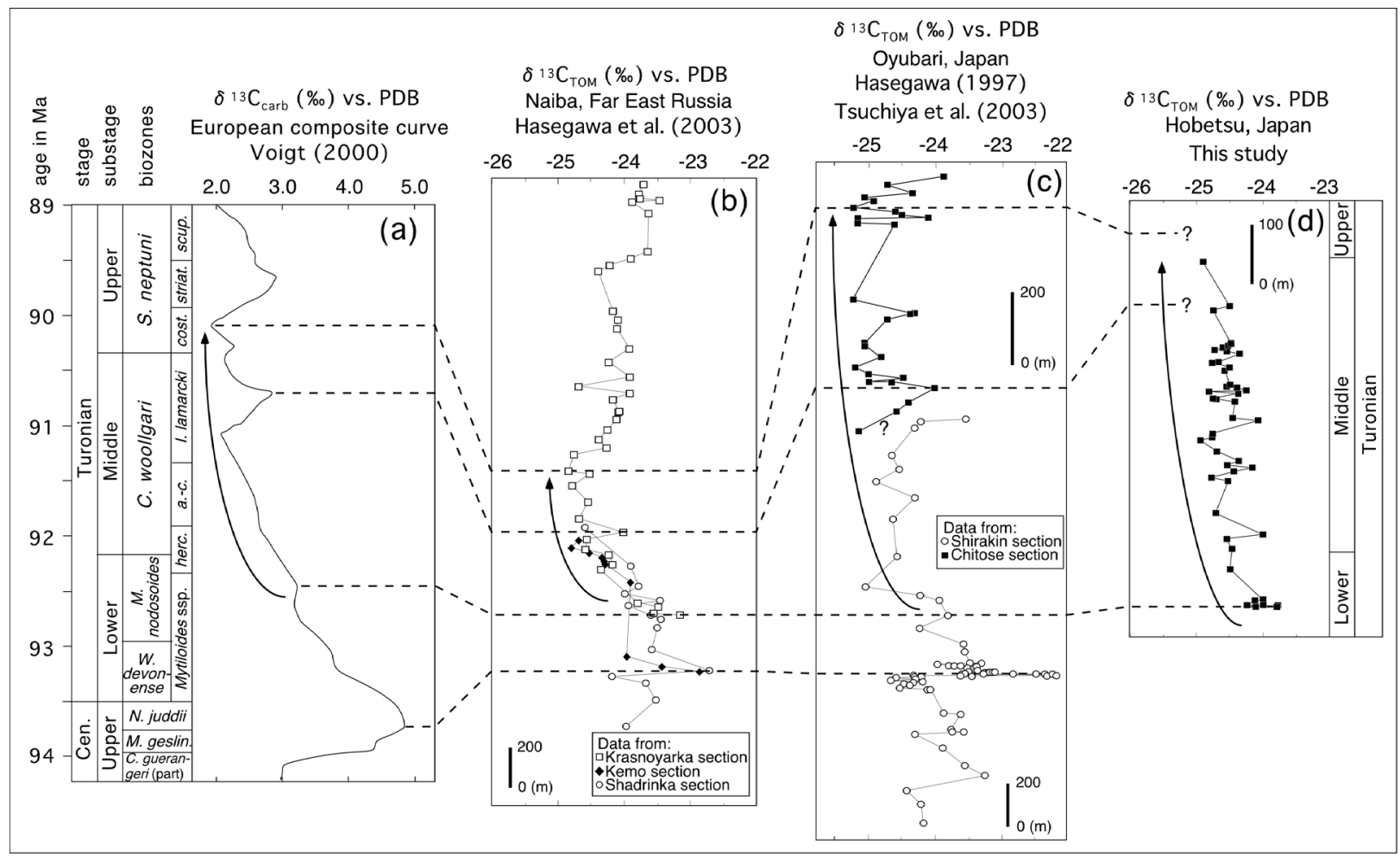

Fig. 8. Comparison of carbon-isotope profiles for carbonate (a) and terrestrial organic matter (b), (c), (d) modified after Hasegawa (2003b). Broken lines show correlative $\delta^{13} \mathrm{C}$ events. Stage boundaries for the Hobetsu area are based on biostratigraphy discussed in this study.

か存在するが，これらと炭素同位体比の変動との関係を考察 する (Fig. 6). I. hobetsensis (s. l.) の産出範囲より下位の 区間は, Lower Turonian 亜階に当たるが, 炭素同位体比は およそー $24.0 \%$ \%ら $-24.5 \%$ \%の負方向への変動を示す. この上位の Middle Turonian 亜階下部にあたるI. hobetsensis (s. 1.) の産出範囲に入ってからも更に負へのシフト傾向 は続き, H. cf. helvetica の初産出層準の上位約 $50 \mathrm{~m}$ で極 小值をとる (YKJ-221; - 24.9\%). その直上から正にシフト し始め, M. pseudolinneiana の初産出層準の下位約 $50 \mathrm{~m}$ (YKJ-218; - 24.5\%) より上位では $0.5 \%$ の幅を持って変動 を繰り返す，この傾向は, 当ルートで浮遊性有孔虫が産出す る最上部の, KS21/KS22 帯境界付近と考えられる層準の上 位約 $70 \mathrm{~m}$ まで続く. Upper Turonian 塜階最下部に当たる I. teshioensis の産出層準（YKS-103）では 1 層準のみであ るが, $-24.9 \%$ となり，再び減少する (Fig. 6) .

Hasegawa（2003b）は大型化石を用い, 大夕張地域・達 布地域及びサハリン南部ナイバ地域とヨーロッパの Turonian 階を対比させ, Turonian 階において北海道及びサハリン の陸源有機炭素同位体比とヨーロッパの炭酸塩炭素同位体比 が類似した変動を示すことを明らかにした. Hasegawa （2003b）の同位体比曲線の比較からは, Cenomanian/Turonian 階境界の正のスパイク直後の負方向へのシフトバック とそれに続くステップ状の安定期を経た後に, Lower Turonian 亜階上部から Upper Turonian 亜階最下部にかけて炭 素同位体比は $1.0 \sim 1.5 \%$ の負のシフトを示す大局的なパ夕
ーンを読み取ることができる，同様な約 $1.0 \%$ の大局的な負 方向への変動傾向は鍛治屋の沢ルートを通じて見られる (Fig. 8 の矢印)。このような大局的な変動に加え, Hasegawa (2003b) は, I. hobetsensis の層序的産出範囲の 中部付近に見られる炭素同位体比の約 $1 \%$ の正のエクスカー ションをIH スパイクと呼び，ヨーロッパで Middle Turonian 亜階の Collignoniceras woollgari 帯中部に典型的に見 られる顕著な正のエクスカーション（例えば, Wiese and Kaplan, 2001）に対比できると考えた. 鍛冶屋の沢ルートで はI. hobetsensis (s. 1.) の産出範囲下限の上位約 $160 \mathrm{~m}$ でー24.9\%の極小值をとった直後に, 約 $1 \%$ 正方向への小 エクスカーションが見られる. この小エクスカーションは $I$. hobetsensis 帯にあり, Hasegawa (2003b) のIH スパイク に対応する可能性がある。しかし，IH スパイクの年代は Voigt（2000）に対比すれば約 90.7 Ma であり，KS21/KS22 帯境界（91.31 Ma; Hardenbol et al., 1998）よりわずかに 若く, 本地域ではこの正の小エクスカーションが KS21 帯に 含まれている. したがって, この小エクスカーションは Middle Turonian 亜階に汎世界的に見られるIH スパイクに 相当しないものと考えるのが妥当であろう.ただし，IH ス パイクと H. helvetica の産出範囲について詳細に研究した 例はなく, 断定はできない. 生層序学的フレームワークに基 づけば，当ルートにおいて IH スパイクに相当する炭素同位 体比の変動が存在する可能性が高い層位範囲はYKJ-201 か ら YKS-103 までの約 $150 \mathrm{~m}$ である.この区間は比較的試料 
間隔が広いために，エクスカーションに相当する層準が露出 していなかったのか, 若しくはYKS-103 以上の層準で，鍛 冶屋の沢ルートに分布する区間より上位にあるために確認で きなかった可能性がある。

\section{Archaeoglobigerina 属 2 種とH. helvetica の産出 層序関係に関する考察}

H. helvetica は Early-Middle Turonian 期にのみ生存した 種であり, その全生存期間が浮遊性有孔虫帯の KS21 帯（H. helvetica 帯) と定義されている. 一方, Archaeoglobigerina 属は，これまで年代指標種として用いられてはこなか った. しかし, Caron (1985) ではDicarinella primitiva 帯の基底部にArchaeoglobigerina cretacea，同帯中部以 上にArchaeoglobigerina blowi の FAD を示している. Premoli Silva and Sliter（1999）では，それよりわずかに下 位の KS22 帯 (Dicarinella primitiva-Marginotruncana sigali Zone）中部がArchaeoglobigerina 属の初出現であ るとしており，膨大な試料を検討した両研究のどちらにおい てもKS21 帯より上位でArchaeoglobigerina 属が出現す ると考えている (Fig. 5). 本研究では A. blowi および A. cretaceaはKS21 帯で出現しており, 上記の両研究と食い 違う。本山ほか（1991）は, 本研究地域に北接する大夕張 地域で, A. cretacea とA. blowi の初産出する層準が，大型 化石では Turonian 階を示す層準であることを問題として提 起している.

以下に大型化石と炭素同位体比層序の観点から $A$. cretacea とA. blowi の初産出の層準の評価を試みる. Hirano et al. (1989, 1991）によれば，本山ほか（1991）の示し た A. cretacea とA. blowi の初産出は, 国際的に Middle Turonian 亜階（一部 Upper Turonian 亜階にかかる）の指 標種である Collignoniceras woollgari (Mantell) と, 日 本における Middle Turonian 亜階の代表種とされるInoceramus hobetsensis の 2 種の層序的産出範囲に含まれてい る. 本研究でも Archaeoglobigerina 属 2 種の産出地点と ほぼ一致する層準でI. hobetsensis（s. l.）を得ている. Hasegawa (2003b) によると, IH スパイクが存在するのは 白金層下部のシルト岩層であり, 本山ほか（1991）が A. cretacea とA. blowi の初産出を報告した層準にほぼ一致す る. 以上のことから, 大夕張地域においてもArchaeoglobigerina 属の 2 種の層序的産出範囲が Middle Turonian 亜 階に始まることは明らかである，すなわち，これら 2 種の $\mathrm{FAD}$ の年代が, 従来知られていた時期よりも古かった, と 言える.

本研究で A. cretacea とA. blowi を産した YKJ-201 は, 前述のように本研究で検討した試料の最上部に当たり, KS21/KS22 帯境界の近傍にあると判断できるが, Hadenbol et al. (1998) によれば，その層準の年代は $91.31 \mathrm{Ma}$ であ る. 大夕張の Archaeoglobigerina 属 2 種の初産出（本山 ほか, 1991）層準の年代は IH スパイクの年代から約 $90.7 \mathrm{Ma}$ と推定されるが (前述), YKJ-201の層準はこれより更に古 い年代を示すことになる.

\section{結 論}

北海道穂別地域の白亜系において浮遊性有孔虫の層序学的 研究を行った結果, 浮遊性有孔虫の層序学的分布は熱帯・亜 熱帯地域の帯区分と比較することができ, Sliter (1989) の 化石帯を認定することができた，それに基づいて，以下の知 見を得た

1）ヌタポマナイ層「主部」の上部から, Helve toglobotruncana helvetica が数層準にわたつて産出し KS21 帯を認定した.

2）産出化石から推定される地質年代は, 稲里層において Middle-Late Cenomanian 期である. ヌタポマナイ層 「主部」においては Middle Turonian 期であり，一部 Late Turonian 期に達する. 化石の産出はなかったが, 上下層との関係からヌタポマナイ層「下部」の地質年代 は, Late Cenomanian 期から Early Turonian 期である と推定される.

3) Helvetoglobotruncana helvetica, Helvetoglobotruncana praehelvetica, Marginotruncana pseudolinneiana, Praeglobotruncana gibba が共産ないし極め て近い層準から産出した. その関係から, 鍛冶屋の沢ル 一トにおいて上部に浮遊性有孔虫帯の KS21/KS22 帯境 界があることが推定された. その層準の P. gibba は従来 日本で報告されていたよりも若い時代のもので, 日本で も H. helvetica の最終出現面（LAD）相当の層準まで同 種が産出することがわかった。

4）鍛冶屋の沢ルートで見られる炭素同位体比の変動は Lower Turonian 亜階から Upper Turonian 亜階最下部 に対比でき，生層序から推定された年代を支持する.

5）これまで層序学的産出範囲が KS22 帯以上に限られると 考えられてきたArchaeoglobigerina 属が H. helvetica と共産することを穂別地域において確認し, 北接する大 夕張地域の過去のデー夕 (Archaeoglobigerina 属と大 型化石の産出状況および炭素同位体比）を合わせて考察 した結果, 北西太平洋域ではArchaeoglobigerina 属が 従来から知られているより早い時代から生存しており, 同属の初産出基準面（FAD）はKS21 帯内の Middle Turonian 亜階に下がることが明らかになった

\section{謝 辞}

本研究を進めるにあたり, 産業技術総合研究所の利光誠一 氏には野外調査において有益な御助言を頂き，大型化石の同 定をして頂いた．京都大学の前田晴良助教授には大型化石の 同定をして頂いた. また, インディアナ大学地質科学教室生 物地球化学研究室の L. M. Pratt 氏には著者らに同大学施設 を使用させて頂き，同 P. Sauer 氏には炭素同位体比分析に 関し協力を頂いた．インディアナ地質調査所の M. Mastalerz 氏には有機物の同定をして頂き，有益な示唆を頂いた。早稲 田大学教育学部の平野弘道教授, および匿名の査読者からは 貴重なご助言を頂き，本稿を改善することができた，道有林 入林に際し胆振森づくりセンターに便宜を図って頂いた。 ま 
た野外調査中の宿泊に関して関谷旅館の皆様にお世話になつ た. 以上の方々に対し, 記して感謝の意を表する. なお，本 研究の一部には日本学術振興会科学研究費補助金基盤研究 C （1）課題番号 13640469 （代表者: 長谷川卓）を使用した.

\section{文}

\section{献}

Bustin, R. M., Cameron, A. R., Grieve, D. A. and Kalkreuth, W. D., 1983, Coal petrology, its principle, methods, and applications. Geol. Assoc. Canada Short Course Note, 3, Geol. Assoc. Canada, Victoria, 230p.

Caron, M., 1985, Cretaceous planktonic foraminifera. In Bolli, H.M., Saunders J. B. and Perch-Nielsen, K., eds., Plankton Stratigraphy, Cambridge Univ. Press, 17-86

Frakes, L. A., 1999, Estimating the global thermal state from Cretaceous sea surface and continental temperature data. In Barrera, E. and Johnson, C. C., eds., Evolution of the Cretaceous ocean-climate system, Geol. Soc. Amer. Spec. Pap., no.332, Boulder, 49-57.

Frakes, L. A., Francis, J. E. and Syktus, J. I., 1992, Climate modes of the Phanerozoic. Cambridege Univ. Press, 274p.

Hardenbol, J., Thierry, J., Farley, M.B., Jacquin, T., de Graciansky, P. C. and Vail, P. R., 1998, Mesozoic and Cenozoic sequence chronostratigraphic framework of European basins. SEPM Spec. Pub., no. 60, 313,8 charts

Hasegawa, T., 1995, Correlation of the Cenomanian/Turonian boundary between Japan and Western Interior of the United States. Jour. Geol. Soc. Japan, 101, 2-12.

Hasegawa, T., 1997, Cenomanian-Turonian carbon isotope events recorded in terrestrial organic matter from northern Japan. Palaeogeogr. Palaeoclimatol. Palaeoecol., 130, 251-273.

Hasegawa, T., 1999, Planktonic foraminifera and biochronology of the Cenomanian-Turonian (Cretaceous) sequence in the Oyubari area, Hokkaido, Japan. Paleont. Res., 3, no. 3, 173-192, 9 figs.

長谷川卓, 2000, 白亜紀 Cenomanian/Turonian 期境界の海洋無酸素事 変. 月刊地球号外, no. 29, 166-177.

Hasegawa, T., 2001, Predominance of terrigenous organic matter in Cretaceous marine fore-arc sediments, Japan and Far East Russia. Intern. Jour. Coal Geol., 47, 207-221.

長谷川卓, 2003a, 有機物の炭素同位体比を用いた古環境解読の試み. 地質ニュース, no. 586, 4-11.

Hasegawa, T., 2003b, A global carbon-isotope event in the Middle Turonian (Cretaceous) sequences in Japan and Russian Far East. Proc. Japan Acad., 79, ser. B, no. 6, 141-144.

Hasegawa, T. and Hatsugai, T., 2000, Carbon-isotope stratigraphy and its chronostratigraphic significance for the Cretaceous Yezo Group, Kotanbetsu area, Hokkaido, Japan. Paleont. Res., 4, no. 2, 95-106.

Hasegawa, T., Pratt, L. M., Maeda, H., Shigeta, Y., Okamoto, T., Kase, T. and Uemura, K., 2003, Upper Cretaceous stable carbon isotope stratigraphy of terrestrial organic matter from Sakhalin, Russian Far East: proxy for the isotopic composition of paleoatmospheric $\mathrm{CO}_{2}$. Palaeogeogr. Palaeoclimatol. Palaeoecol., 189, 97-115.

Hasegawa, T. and Saito, T., 1993, Global synchroneity of a positive carbon isotope excursion at the Cenomanian/Turonian boundary: validation by calcareous microfossil biostratigraphy of the Yezo Group, Hokkaido, Japan. Island Arc, 3, 181-191.

平野弘道・安藤寿男・平川正人・森田利仁 - 石川 享, 1981, 北海道大 夕張地域南部の化石層序学的研究. 第 2 部. 早稲田大教育学術研 究 (生物学・地学編), 30, 33-45.

Hirano, H., Takizawa, K. and Tsuchida, S., 1989, Biostratigraphy of the Upper Cretaceous in the Oyubari area, central Hokkaido, Japan (I) . Bull. Sci. Engin. Res. Lab. Waseda Univ., 123, 13-34.

Hirano, H., Takizawa, K. and Tsuchida, S., 1991, Biostratigraphy of the Upper Cretaceous in the Oyubari area, central Hokkaido, Japan (IV).
Bull. Sci. Engineering Res. Lab. Waseda Univ., 127, 8-26.

米谷盛壽郎・井上洋子, 1973, 微化石研究のための効果的岩石処理につ いて. 化石, nos. 25 • 26, 87-96.

Marianos, A. W. and Zingula, R. P., 1966, Cretaceous planktonic foraminifers from Dry Creek, Tehama County, California. Jour. Paleontol., 40, 328-342.

Matsumoto, T., 1942, Fundamentals in the Cretaceous stratigraphy of Japan. Part I. Mem. Fac. Sci. Kyushu Imp. Univ., ser. D, 1, 129-280.

Matsumoto, T., 1943, Fundamentals in the Cretaceous stratigraphy of Japan. Part II, III. Mem. Fac. Sci. Kyushu Imp. Univ., ser. D, 2, 98237.

松本達郎・野田雅之・蟹江康光・吉川幸叙・利光誠一・米谷盛壽 郎・花方 聡, 1994, 北海道穂別地域におけるセノマニアン・チュ ロニアン推移部の層序. 穂別町立博研報, no. 10, 1-25.

松本達郎・野田雅之・米谷盛寿郎, 1991, 北海道白亜系セノマニアン・ チュロニアン両階のアンモナイト・イノセラムス・有孔虫による 統合生層序を目指して. 地学雑, 100, 378-398.

松本達郎・野田雅之・利光誠一, 1989, 穂別町立博物館の巨大アンモナ イトーその産出記録と層位. 穂別町立博研報, no. 5, 13-25, pls. I-II.

本山 功・藤原 治・海保邦夫 - 室田 隆, 1991, 北海道大夕張地域の 白亜系の層序と石灰質微化石年代. 地質雑, 97, 507-527.

Nishi, H., Takashima, R., Hatsugai, T., Saito, T., Moriya, K., Ennyu, A. and Sakai, T., 2003, Planktonic foraminiferal zonation in the Cretaceous Yezo Group, central Hokkaido, Japan. Jour. Asian Earth Sci., 21, 867-886.

西田民雄・松本達郎 - 久間裕子 - 米谷盛寿郎, 1992, 北海道古丹別川流 域白亜系セノマニアン・チュロニアンのイノセラムスー有孔虫統 合生層序. 佐賀大教育研究論文集, 39, 21-59.

Premoli Silva, I. and Sliter, W.V., 1999, Cretaceous paleoceanography: evidence from planktonic foraminiferal evolution. In Barrera, E. and Johnson, C. C., eds., Evolution of the Cretaceous Ocean-Climate System, Geol. Soc. Amer. Spec. Pap., Boulder, no.332, 301-328.

Sliter, W.V., 1989, Biostratigraphic zonation for Cretaceous planktonic foraminifers examined in thin section. Jour. Foram. Res., 19, 1-19, pls.1-3.

高橋功二 - 谷口久能 - 渡辺 順 - 石丸 聡, 2002,5 万分の 1 地質図幅 「紅葉山」および説明書. 北海道立地質研究所, $117 \mathrm{p}$.

高橋功二 - 和田伸彦, 1985, 穂別町の地質. 穂別町立博研報, no. 2, 115 .

高嶋礼詩・西 弘嗣・斎藤常正・長谷川卓, 1997, 北海道シューパロ川 流域に分布する白亜系の地質と浮遊性有孔虫化石層序. 地質雑, 103, 543-563.

Takayanagi, Y., 1960, Cretaceous foraminifera from Hokkaido, Japan. Sci. Rept. Tohoku Univ., Second Ser. (Geol), 32, no. 1, 1-154.

Toshimitsu, S. and Maiya, S., 1986, Integrated inoceramid-foraminiferal biostratigraphy of Upper Cretaceous of northwestern Hokkaido, Japan. Cret. Res., $7,307-326$.

利光誠一 - 松本達郎 - 野田雅之 - 西田民雄 - 米谷盛寿郎, 1995, 本邦上 部白亜系の大型化石一微化石層序および古地磁気層序の統合に向 けて。地質雑, 101, 19-29.

土屋 健・長谷川卓・リサ M. プラット, 2003, 北海道蝦夷層群にお ける炭素同位体比曲線とイノセラムス生層序の対応関係. 地質 雑, 109, 30-40.

Voigt, S., 2000, Cenomanian-Turonian composite $\delta^{13} \mathrm{C}$ curve for Western and Central Europe: the role of organic and inorganic carbon fluxes. Palaeogeogr. Palaeoclimatol. Palaeoecol., 160, 91-104.

Wiese, F. and Kaplan, U., 2001, The potential of the Lengerich section (Münster basin, northern Germany) as a possible candidate Global boundary Stratotype Section and Point (GSSP) for the Middle/Upper Turonian boundary. Cret. Res., 22, 549-563.

Zachos, J., Pagani, M., Sloan, L., Thomas, E. and Billups, K., 2001, Trends rhythms, and aberrations in global climate 65 Ma to present. Science, 292, 686-693 
(要 旨)

山本真也・長谷川卓, 2006, 北海道穂別地域に分布するセノマニアンーチューロニアン階の浮 遊性有孔虫層序. 地質雑，112，243-256. (Yamamoto, S. and Hasegawa, T., 2006, Planktonic foraminiferal biostratigraphy of the Cenomanian-Turonian sequence in the Hobetsu area, Hokkaido, Japan. Jour. Geol. Soc. Japan. 112, 243-256.)

北海道穂別北部地域の Middle-Upper Turonian 亜階で，国際的に年代指標性のある浮遊 性有孔虫が連続的に産出し, 重要な浮遊性有孔虫帯境界である Helvetoglobotruncana helvetica 帯上限の層序学的位置を推定することができた，更に，国際的に同種と共産す るとされている浮遊性有孔虫 3 種との共産が確認され，鍛冶屋の沢ルートの上部がほぼ $H$. helvetica 帯最上部であることが明らかになった．同ルートの炭素同位体比の変動は，汎 世界的な Middle-Upper Turonian 亜階の変動と調和的であり, 浮遊性有孔虫層序から推定 された年代を支持する.

また, Middle Turonian 亜階で Archaeoglobigerina 属が H. helvetica と共産することか ら, 同属の初出現の時期は従来の知見より古いことが示された. 